\title{
Methane/Ammonia Radical Formation during High Temperature Reactions in Swirl Burners
}

\author{
Marco Osvaldo Vigueras-Zúñiga ${ }^{1}$, Maria Elena Tejeda-del-Cueto ${ }^{1}{ }^{\circ}$, Syed Mashruk $\left.{ }^{2}{ }^{(}\right)$, Marina Kovaleva ${ }^{2}$, \\ Cesar Leonardo Ordóñez-Romero ${ }^{3}$ and Agustin Valera-Medina ${ }^{2, *(1)}$
}

1 School of Engineering, Universidad Veracruzana, Veracruz 94294, Mexico; mvigueras@uv.mx (M.O.V.-Z.); etejeda@uv.mx (M.E.T.-d.-C.)

2 College of Physical Sciences and Engineering, Cardiff University, Cardiff CF243AA, UK; mashruks@cardiff.ac.uk (S.M.); kovalevam@cardiff.ac.uk (M.K.)

3 Instituto de Física, Universidad Nacional Autónoma de México, Ciudad de México 04510, Mexico; cloro@fisica.unam.mx

* Correspondence: valeramedinaa1@cardiff.ac.uk

\section{check for} updates

Citation: Vigueras-Zúñiga, M.O.; Tejeda-del-Cueto, M.E.; Mashruk, S.; Kovaleva, M.; Ordóñez-Romero, C.L.; Valera-Medina, A.

Methane/Ammonia Radical Formation during High Temperature Reactions in Swirl Burners. Energies 2021, 14, 6624. https://doi.org/ $10.3390 /$ en14206624

Academic Editor: Andrzej Teodorczyk

Received: 9 September 2021

Accepted: 8 October 2021

Published: 14 October 2021

Publisher's Note: MDPI stays neutral with regard to jurisdictional claims in published maps and institutional affiliations.

Copyright: (c) 2021 by the authors. Licensee MDPI, Basel, Switzerland. This article is an open access article distributed under the terms and conditions of the Creative Commons Attribution (CC BY) license (https:/ / creativecommons.org/licenses/by/ $4.0 /)$.

\begin{abstract}
Recent studies have demonstrated that ammonia is an emerging energy vector for the distribution of hydrogen from stranded sources. However, there are still many unknown parameters that need to be understood before ammonia can be a substantial substitute in fuelling current power generation systems. Therefore, current attempts have mainly utilised ammonia as a substitute for natural gas (mainly composed of methane) to mitigate the carbon footprint of the latter. Co-firing of ammonia/methane is likely to occur in the transition of replacing carbonaceous fuels with zero-carbo options. Hence, a better understanding of the combustion performance, flame features, and radical formation of ammonia/methane blends is required to address the challenges that these fuel combinations will bring. This study involves an experimental approach in combination with numerical modelling to elucidate the changes in radical formation across ammonia/methane flames at various concentrations. Radicals such as $\mathrm{OH}^{*}, \mathrm{CH}^{*}, \mathrm{NH}^{*}$, and $\mathrm{NH}_{2}{ }^{*}$ are characterised via chemiluminescence whilst $\mathrm{OH}, \mathrm{CH}, \mathrm{NH}$, and $\mathrm{NH}_{2}$ are described via RANS $\kappa-\omega$ SST complex chemistry modelling. The results show a clear progression of radicals across flames, with higher ammonia fraction blends showing flames with more retreated shape distribution of $\mathrm{CH}^{*}$ and $\mathrm{NH}^{*}$ radicals in combination with more spread distribution of $\mathrm{OH}^{*}$. Simultaneously, equivalence ratio is a key parameter in defining the flame features, especially for production of $\mathrm{NH}_{2}{ }^{*}$. Since $\mathrm{NH}_{2}{ }^{*}$ distribution is dependent on the equivalence ratio, CFD modelling was conducted at a constant equivalence ratio to enable the comparison between different blends. The results denote the good qualitative resemblance between models and chemiluminescence experiments, whilst it was recognised that for ammonia/methane blends the combined use of $\mathrm{OH}, \mathrm{CH}$, and $\mathrm{NH}_{2}$ radicals is essential for defining the heat release rate of these flames.
\end{abstract}

Keywords: ammonia; hydrogen; combustion; methane; radicals; chemiluminescence; CFD

\section{Introduction}

Ammonia has received considerable attention due to its potential to decarbonise power generation systems at land, sea, and air. Ammonia's characteristics (e.g., being in a liquid state at $-33{ }^{\circ} \mathrm{C}$ under atmospheric pressure, or $\sim 0.8 \mathrm{MPa}$ at atmospheric temperature [1]), its hydrogen content [2], and the extensive and mature infrastructure that exists worldwide make it a good candidate for these applications [3]. Currently, comparisons with other fuels have shown that ammonia's versatility can enable its use for combustion or in fuel cell devices [4], potentially delivering greater hydrogen quantities than other options (i.e., liquid organic hydrogen carriers, LOHC) at lower costs. Similarly, life cycle analyses denote how ammonia-fuelled systems present great potential to deliver green, sustainable 
stranded hydrogen [5-7] whilst reducing greenhouse emissions in support of the reduction in large carbon footprint scenarios.

However, there are remaining technical challenges before ammonia can be used for large scale power generation. Toxicity, corrosivity, and large production of nitrogen oxides (NOx) seem to be the greatest of the current barriers for full deployment of the molecule as an energy vector. Furthermore, poor flame stability complicates the use of this molecule as a replacement for fossil fuel.

Interestingly, detailed reports [8,9] show that ammonia is a chemical that can be easier to handle than other options (such as LPG) when fuelling transportation devices, whilst the chemical's lower diffusivity can also be beneficial when compared with pure hydrogen in the context of leakages [10]. Further analyses also show that ammonia's ignition probability in collision is considerably lower than most hydrocarbons [11]. However, it is agreed that ammonia is highly toxic for aquatic life [12] and that it has impacts on human health more in relation to corrosive-dehydrating processes through the respiratory tract [13]. This is a considerable problem under confined conditions that do not necessarily need to be employed for large power generation concepts. In terms of corrosion of materials, removal of copper-based components with advanced coating can alleviate this barrier.

However, emissions (especially nitrogen oxides), pollution (particle formation), and flame stability pose a more fundamental issue. For this reason, considerable research is underway to understand the reaction mechanism of ammonia blends. Work ranges from micro generation to large scale production [14], and in terms of gas turbines, considerable work has been progressing since the resurrection of the concept in Japan [15]. Pure ammonia blends, despite being more difficult to burn, have been successfully used for medium-size applications [16,17], whilst ammonia/hydrogen blends have provided results with potential for reduction in emissions, improved flame stability, and enhanced operability range [18]. The addition of other agents, such as steam, may also play a role in mitigating emissions via the production of $\mathrm{O}, \mathrm{H}$, and $\mathrm{OH}$ radical pools under rich conditions to further bring down $\mathrm{NO}_{x}$ [19]. Injection strategies in combination with new cycles have also elucidated the complexity of hydrogen-nitrogen-oxygen reactions that can be manipulated to enhance stability whilst avoiding the production of large concentrations of $\mathrm{NO}_{x}$ emissions $[20,21]$. Similarly, considerable effort has been dedicated to the use of ammonia/methane or other hydrocarbon combinations for co-firing. Although methane is the base of natural gas, ammonia is intended as a decarbonising co-firing agent that ensures a pronounced reduction in $\mathrm{CO}_{2}$ emissions whilst enabling minimum retrofitting in current units, thus making ammonia/methane blends crucial for the progression of the technology at industrial scale. Initial work on the use of units capable of utilising ammonia/methane blends stem from initial ammonia/kerosene studies [22] that progressed to methane/ammonia experimental campaigns in a $50 \mathrm{~kW}$ power unit [23,24]. Results denoted the intrinsic instability of using two fuels with different reaction characteristics. Furthermore, research advanced towards the use of various blends at various equivalence ratios have shown a reduced operability range at low Reynolds numbers with a unitary swirl number, a dynamic process that at higher ammonia concentrations would improve through a sudden change of combustion dynamics [25]. Simultaneously, other studies with ammonia/methane showed that the region of 1.05-1.20 equivalence ratio would be the best for operation of these blends, as the production of NO decreases due to the excess in ammonia and amidogen radicals (which recombine with NO produced downstream). Under these rich conditions, $\mathrm{CO}$ production can still be controlled through post-combustion $[23,26,27]$. Recent studies also suggest the formation of soot whilst highlighting the need for a better understanding between fuel-nitrogen interactions [28]. These works have been accompanied by novel kinetic modelling [29] and comparisons between models in which complex 3D numerical rigs were made [30]. Further research has also assessed new methods and geometries employed at various scales and optimised for ammonia combustion, from micro-combustors [31] to large power systems [32,33]. 
Novel and ingenious advances have been proposed for the application of these fundamentals in the use of ammonia/methane blends for robust engine designs [34]. However, there are still many unknown parameters in the use of these blends, and further research is needed to acknowledge the impacts of replacing fuels, especially with ammonia/methane blends. Therefore, the present work intended to characterise various ammonia/methane blends and to describe how the changes in flame, radical formation, and stability can affect swirling burners-the most deployed technology for fluid stabilization in gas turbines. This research focused on the recognition of flame modes, thus informing developers on how a change in blend composition can impact the flame, whilst providing data for retrofitting purposes.

\section{Methods}

A tangential swirl burner was employed at $8 \mathrm{~kW}$ power and 1.05 swirl, as shown by Figure 1. The unit was fed using Bronkhorst mass flow controllers that enabled a precision of $0.5 \%$ within the $15-95 \%$ range of the mass flow rate. The unit was fed using hydrogen, ammonia, and methane, as detailed in Table 1. Various conditions were assessed to determine the impact of equivalence ratio on temperature, emissions, spectroscopy, and radical formation.

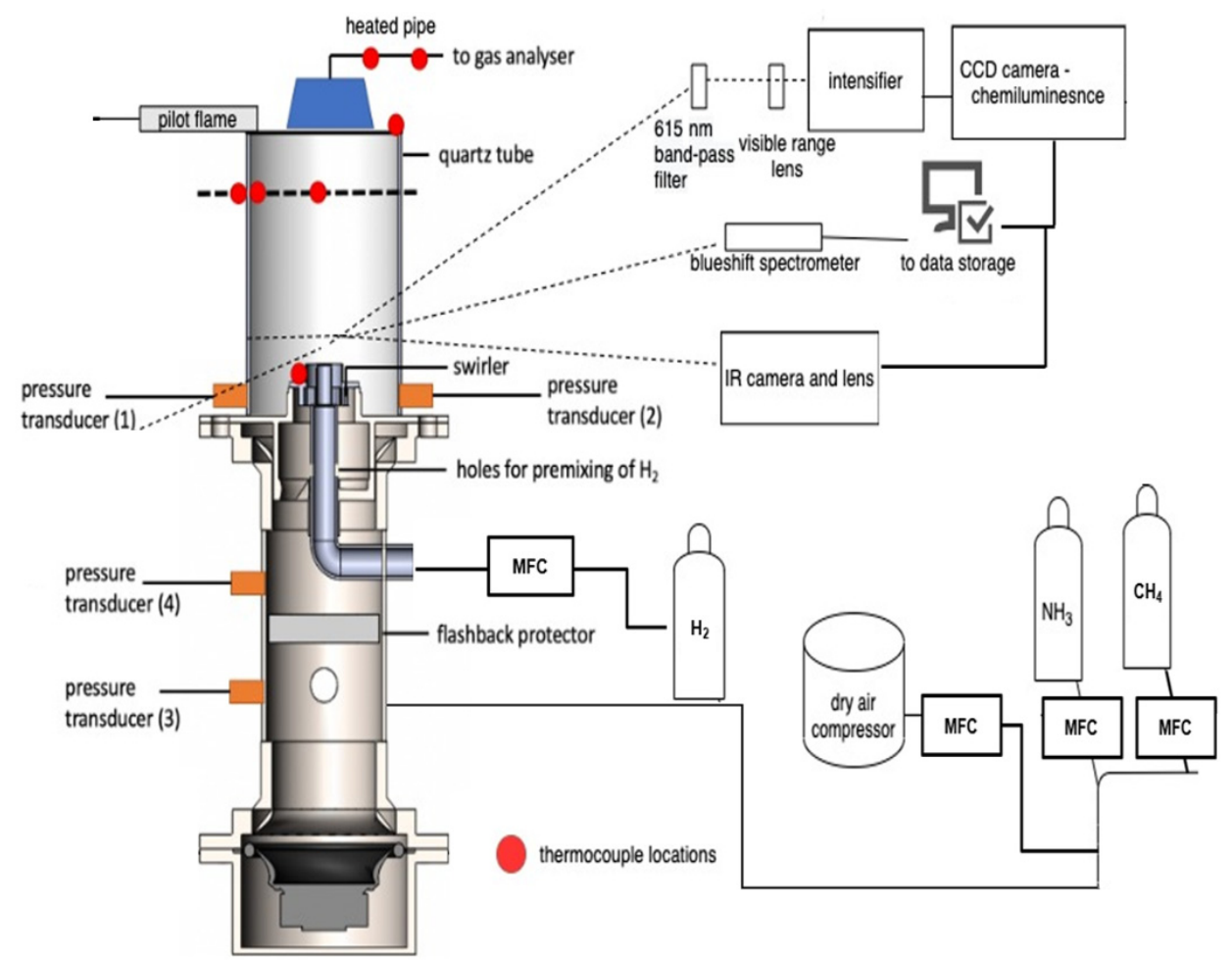

Figure 1. Tangential combustor with measuring techniques and control systems.

Table 1. Experimental and numerical $\left(^{*}\right)$ boundary conditions.

\begin{tabular}{cccc}
\hline Parameter & Value & Parameter & Value \\
\hline Blends $\mathrm{CH}_{4} / \mathrm{NH}_{3}(\mathrm{vol} \%)$ & $20 / 80,40 / 60,60 / 40$ & Quartz Temperature & $1185,1177,1190 \mathrm{~K}$ \\
Mixing & Fully pre-mixed & Burner section & Symmetry $\left(120^{\circ}\right)$ \\
Equivalence Ratios $(\Phi)$ & $0.8,1.0^{*}, 1.2$ & Swirler walls & Adiabatic \\
Power & $8 \mathrm{~kW}$ & Ignition Temperature & $3000 \mathrm{~K}$ \\
Inlet Temperature & $300 \mathrm{~K}$ & Turbulence & $10^{\circ}$ \\
Inlet Pressure & $0.11 \mathrm{MPa}$ & Walls & No-slip \\
Outlet Pressure & $0.10 \mathrm{MPa}$ & Method & Segregated Flow \\
Swirl & 1.05 & Mechanisms & Okafor \\
\hline
\end{tabular}


Sections of the velocity flow field were measured through laser doppler anemometry (LDA) using Dantec Dynamics Flowlite optical systems and processors in conjunction with Windows Software Package-BSA Flow Software. For the section of interest, a 1000-point grid was used with $1 \mathrm{~mm}$ horizontal interval and $1 \mathrm{~mm}$ vertical interval. For every measurement point, the tracer particles used for seeding the fluid i.e., aluminium oxide, were maintained at 10,000, which is above the minimum accuracy threshold count of 2000 [35].

Experiments were conducted at atmospheric pressure and inlet temperature. A pair of LaVision CCD cameras were employed to obtain chemiluminescence traces of various species. The units were triggered simultaneously at a frequency of $10 \mathrm{~Hz}$ and a gain of $85 \%$. Various Edmond filters were used for each species-namely, $\mathrm{OH}^{*}(310 \mathrm{~nm})$, $\mathrm{CH}^{*}(420 \mathrm{~nm}), \mathrm{NH}^{*}(336 \mathrm{~nm})$, and $\mathrm{NH}^{*}(630 \mathrm{~nm})$. LaVision Davis v12 was used to gather 500 frames per flame, which were then post-processed using a MATLAB script designed to conduct Abel deconvolution averaging. Temperature profiles were obtained via $\mathrm{K}$ and R type thermocouples plugged into an RS data logger that was directly linked to a computer. The thermocouples were previously calibrated showing an average error of 3\%. These temperature readings were used as boundary conditions in the CFD simulations. Nitrogen oxides (NO) and carbon monoxide (CO) emissions were measured using a bespoke Emerson CT5100 Quantum Cascade Laser analyser at a frequency of $1 \mathrm{~Hz}$, a repeatability of $\pm 1 \%, 0.999$ linearity, and sampling temperature of up to $190{ }^{\circ} \mathrm{C}$. A heated sampling line at $160{ }^{\circ} \mathrm{C}$ was employed to avoid condensation. These emissions were used for validation purposes between experiments and models.

All chemiluminescence images were standardised through conversion to greyscale. Using a custom script demonstrated by previous studies [23], the background was removed from the image and the $C o G$ was then calculated through extracting the pixel intensity, $I(i, j)$ and position positions $(i, j)$. The $C o G$, further defined in other studies [36], is given by

$$
\operatorname{CoG}=\left[\frac{\sum_{i, j} i \cdot I(i, j)}{\sum_{i, j} I(i, j)}, \frac{\sum_{i, j} j \cdot I(i, j)}{\sum_{i, j} I(i, j)}\right]
$$

After calculating the $C o G$ with respect to every pixel in the image, the resulting value is the pixel location of the intensity-weighted centre of the flame.

A Reynolds averaged Navier-Stokes (RANS) simulation with a finite rate chemistry was conducted using Star-CCM+ v20.1.3 software. Chemistry was described through Okafor's reduced reaction mechanism (42 species and 130 reactions), validated by laminar burning velocity of ammonia/methane mixtures. The $\kappa-\omega$ SST model is utilised for its superior performance for boundary layers under adverse pressure gradients, hence being especially suitable for tangential swirling flows [37,38]. Second-order discretization was employed for convection of segregated flows, whilst curvature correction was applied to the turbulence model to account for the effects of streamline curvature on the evolution of turbulent quantities. For the resolution of combustion, reacting species transport was employed in combination with Eddy Dissipation combustion modelling An eight-core workstation reduced computational time through parallel processing. CFD simulations were only performed on the stoichiometric $(\varphi=1)$ cases.

Combustion analyses were validated using emission results from the experimental campaigns. A computational grid consisting of 4.1 million cells and representing one-third of the burner section was used to represent the entire geometry, as shown in Figure 2, with periodic interface boundaries used to replicate the rotational symmetry of the burner. Through local mesh refinement techniques, the mesh was refined downstream of the burner at the nozzle at the edges of the CRZ and shearing flow formation regions [39]. Preliminary characterisation was conducted for a mesh independency analysis, comparing a coarse grid of $~ 3.1$ million cells, a medium grid of 4.1 million cells, and a fine grid of 7.5 million cells. The intermediate mesh demonstrated similar results to the fine mesh, even at $2 / 3 \mathrm{~s}$ of the time for resolution, while residuals were maintained below 10-4 for the solved simulation. 

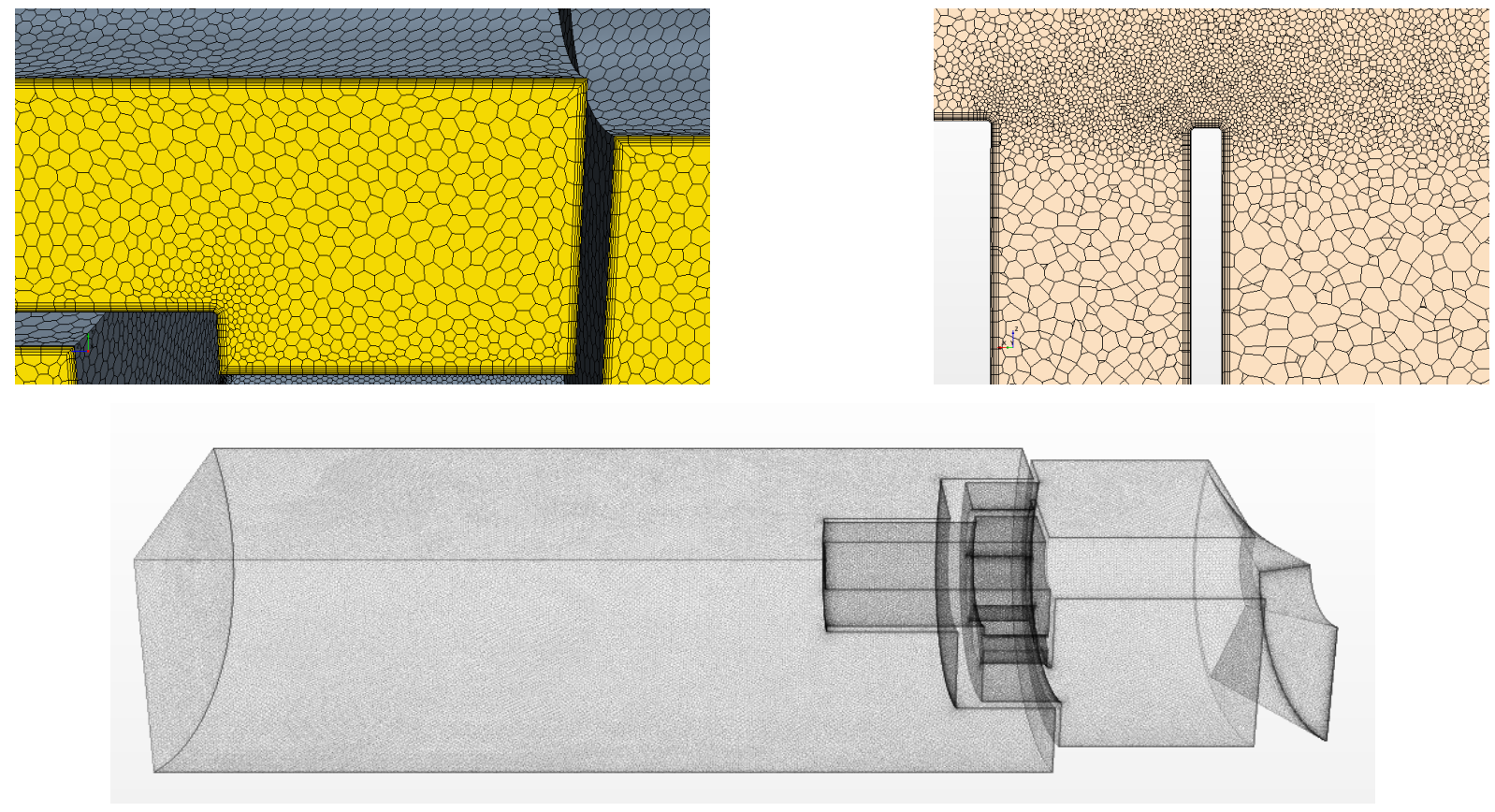

Figure 2. Mesh. (upper left) Periodic mesh; (upper right) refined core; (bottom) entire mesh.

Initial calculations were compared with isothermal experiments in order to determine whether the hydrodynamics of the systems were in accord with those of the numerical model. The results, Figure 3, show evidence of good accuracy between the model and experiments, with the same trends, peak values, and shearing flow location. Therefore, having confidence in the hydrodynamics of the flow, the study progressed into the use of combustion for evaluation of the reduced mechanism. Results, given by Figure 4, show adequate correlation between species $\left(\mathrm{CO}, \mathrm{CO}_{2}\right.$, and $\mathrm{NH}_{3} ; \mathrm{NO}$ was not possible to validate since its values were out of range of the emissions analyser during the experimental campaign). It is notorious that $\mathrm{CO}$ and $\mathrm{CO}_{2}$ are higher in the CFD simulations than in the experiments for the cases $40 / 60$ and 60/40 (methane/ammonia). It is believed that this is a consequence of the heterogeneous temperature of the confinement, which would need very detailed temperature profiles in the simulations, in combination with the impact of complex structures and surface reactions that RANS modelling cannot account for. These effects have considerable impact on the emissions, as explored elsewhere [40], making the topic an active area of research. However, ammonia is well predicted, whilst $\mathrm{CO}$ and $\mathrm{CO}_{2}$ are determined at similar orders of magnitude. Hence, there was a sufficient level of confidence for using these simulations for further analyses.
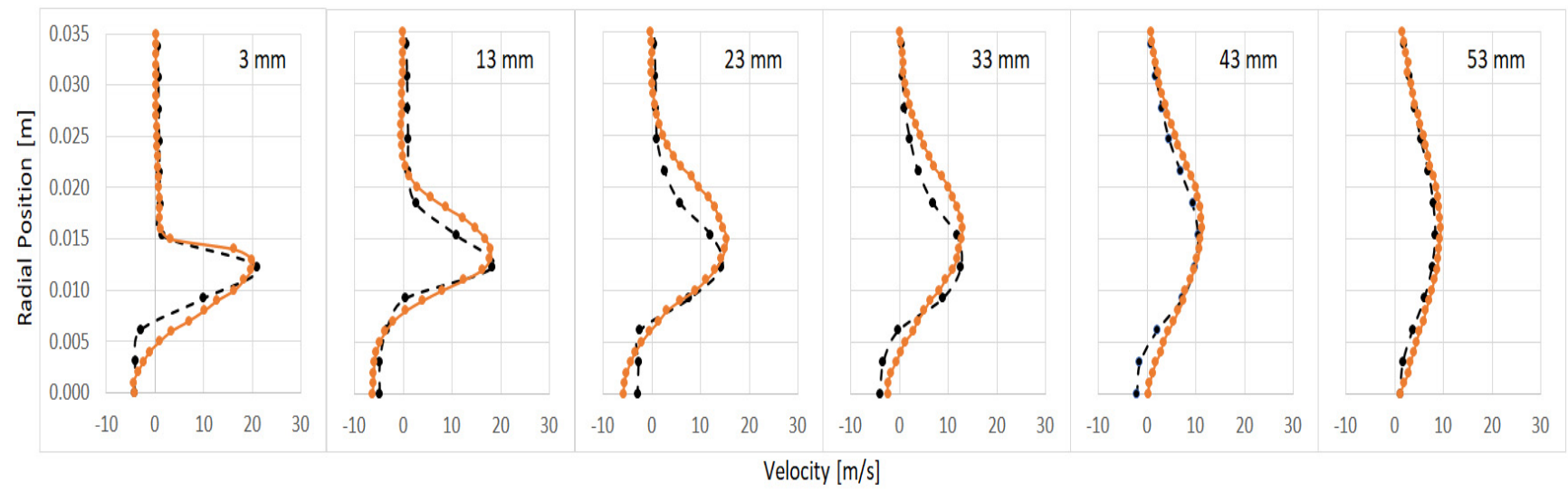

Figure 3. Isothermal results at different axial positions. Experiments (solid, orange line) and numerical (dashed, black line). 


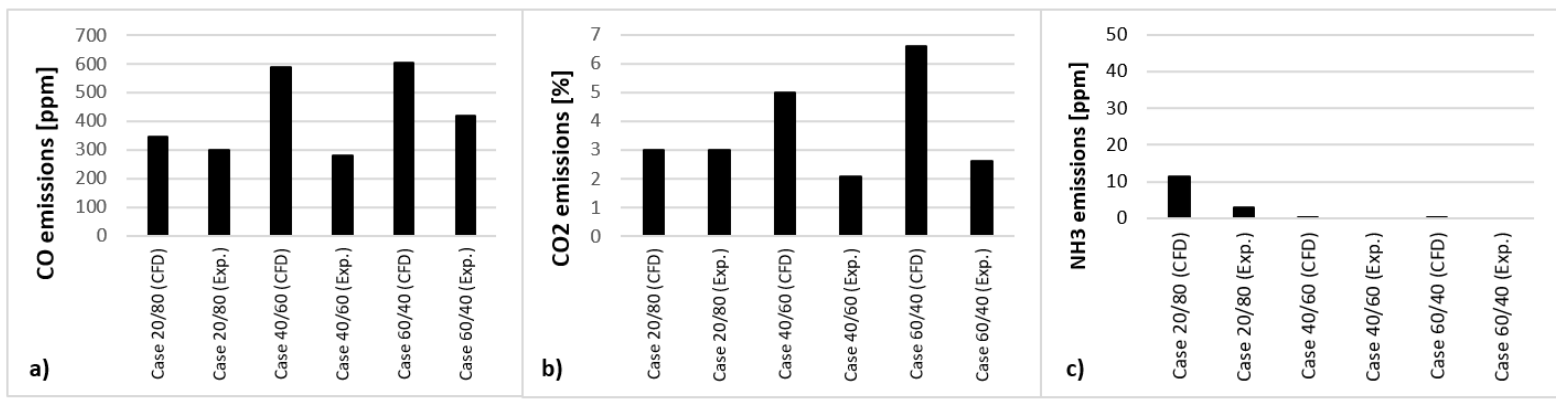

Figure 4. Emission results. (a) $\mathrm{CO}$ (ppm); (b) $\mathrm{CO}_{2}(\%)$; (c) $\mathrm{NH} 3$ (ppm).

\section{Results}

Changes in flame profile were analysed for the various blends described in Table 1. Chemiluminescence data were gathered for $\mathrm{CH}^{*}, \mathrm{OH}^{*}, \mathrm{NH}^{*}$, and $\mathrm{NH}_{2}{ }^{*}$ species (Figure 5). However, the results show great variety of changes between species. Hence, the results were analysed further using CoG characterisation (Figure 6). It is shown how the change in methane/ammonia concentration affects the flame position and radical production. Starting with $\mathrm{CH}^{*}$, it is clear that the increase in methane concentration pushes the production of the radical to outer regions, a trend that is also evident with $\mathrm{NH}^{*}$ and $\mathrm{OH}^{*}$. As would be expected, stoichiometric and lean conditions would lead to more spread and wider $\mathrm{OH}$ radical formation compared with rich conditions where most $\mathrm{OH}^{*}$ is localised within the inner core of the flame as a consequence of oxygen depletion at upper, farther away layers. Similarly, NH production, which is heavily correlated with the presence of $\mathrm{OH}$ radicals in ammonia flames, follows a similar trend to $\mathrm{OH}^{*}$. However, the scenario changes for $\mathrm{CH}$ formation, where the $\mathrm{CH}^{*}$ radicals show wider spread under lean conditions compared with rich or stoichiometric cases. The result reveals the greater tendency of methane to react better in the presence of more oxygen content, as expected, thus producing more $\mathrm{CH}$ radicals under these conditions. It is emphasized that the correlation values in Figure 6 can be improved by adding more samples to the analysis. This is currently under scrutiny by this research group. However, there are clear insights into some prominent trends, as expressed above.

$60 / 40_{\text {vOL. } \%} \mathrm{CH}_{4} / \mathrm{NH}_{3} ; \mathrm{ER}=0.8$
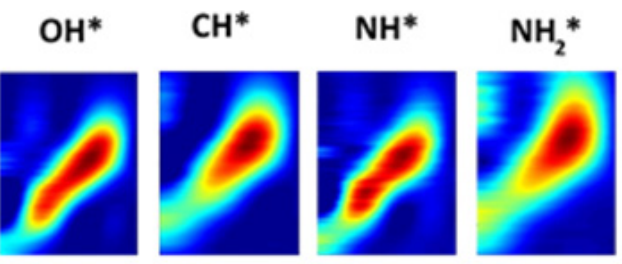

$60 / 40_{\text {vol. } 8} \mathrm{CH}_{4} / \mathrm{NH}_{3} ; \mathrm{ER}=1.0$
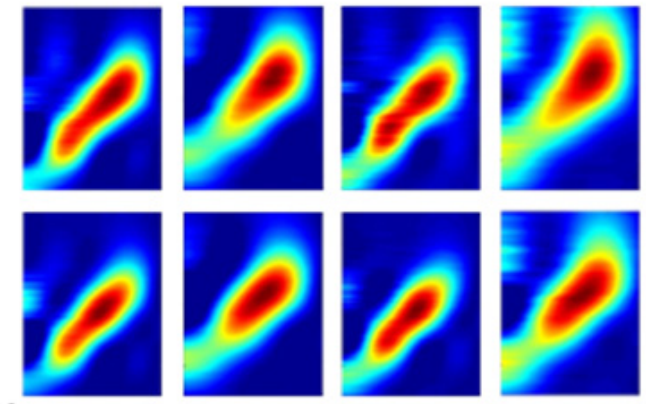

$60 / 40$
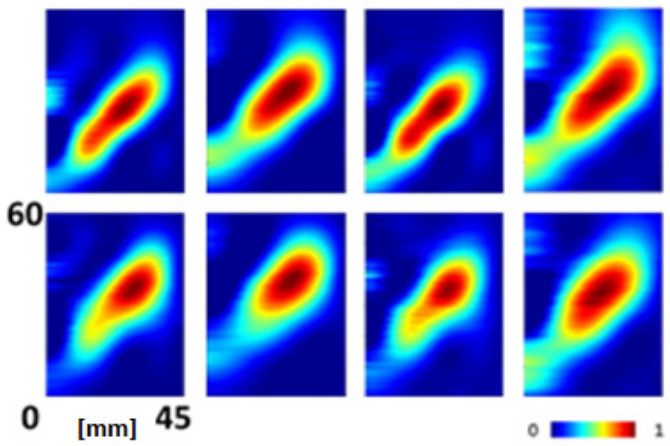

Figure 5. Chemiluminescence analysis for the 60/40 case at various equivalence ratios. Colormap normalized to image dataset max. Similar to this case, other conditions were also obtained with varied results across species. 


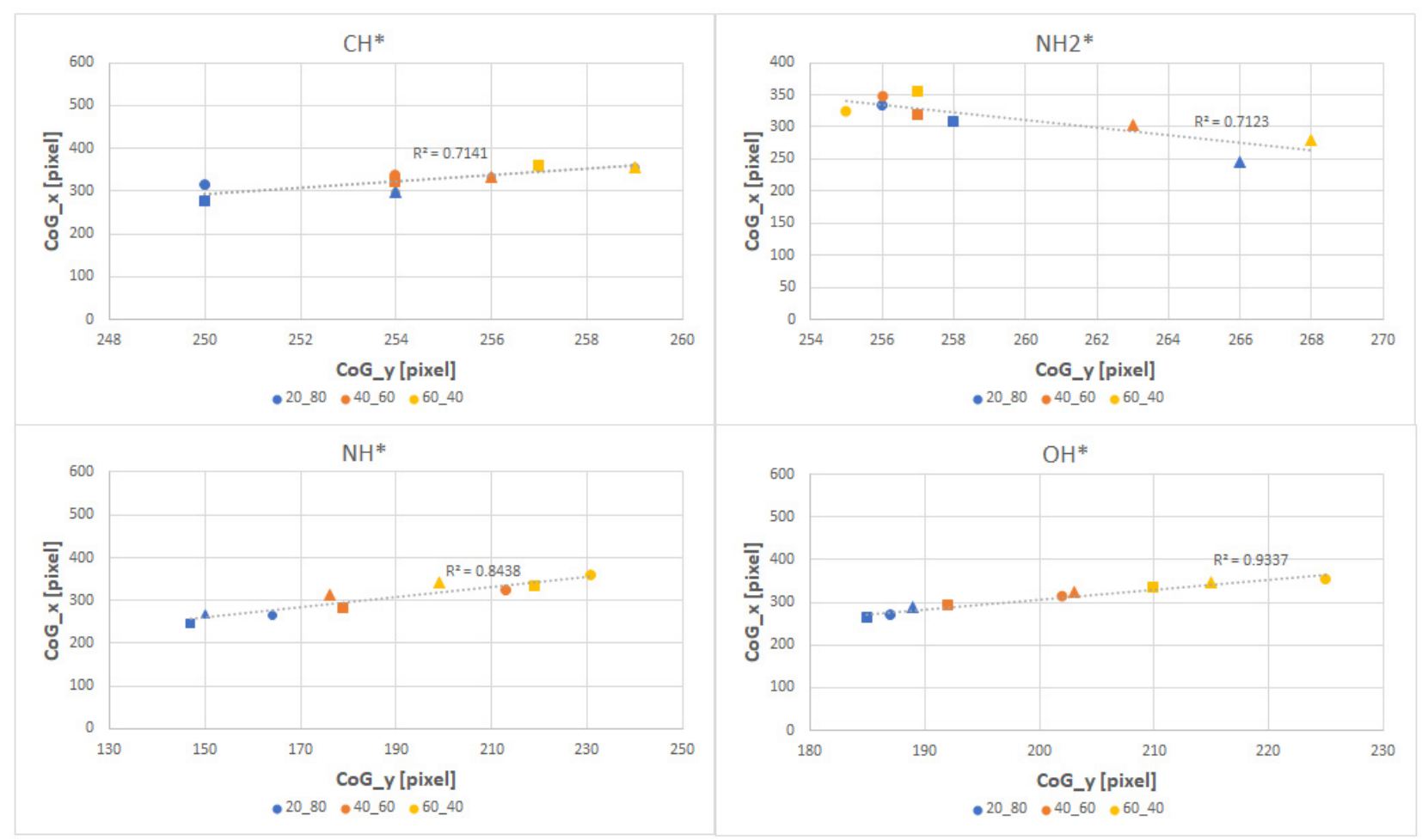

Figure 6. Centre of gravity of chemiluminescence results of various blends (20/80, 40/60, 60/40 vol\% methane/ammonia). Figures $(\bullet)$ stoichiometric, $(\boldsymbol{\Delta})$ lean and $(\boldsymbol{\square})$ rich conditions.

$\mathrm{NH}_{2}{ }^{*}$ acts contrary to those scenarios, which not only seems better correlated with equivalence ratio instead of blend type but also appears to be produced at higher levels under stoichiometric conditions, widening further away from the flame zone and at lower locations under rich and lean conditions, respectively. It was initially predicted that $\mathrm{NH}_{2}{ }^{*}$ would follow a similar trend to that of $\mathrm{NH}^{*}$, especially since the latter is a product of $\mathrm{NH}_{2}+\mathrm{OH} \rightarrow \mathrm{NH}+\mathrm{O} / \mathrm{H} / \mathrm{H}_{2} \mathrm{O}$ reactions. However, the results show that $\mathrm{NH}_{2}$ undergoes further reactions with other species. Moreover, this species is more concentrated within the inner regions of the flame under rich conditions, whilst leaner cases denote a wider, less concentrated distribution of the radical.

The previous results were correlated with flame and radical profiles using CFD modelling, given by Figures 7-9. This part of the study only focused on stoichiometric $(\varphi=1)$ conditions. Figure 7 confirms that the increase in methane in the blend leads to higher temperatures, an expected outcome product of the higher reactivity of methane. This is also accompanied by a shorter flame that shrinks due to the consumption of reactants as a consequence of higher reaction temperatures and faster flames [23]. Interestingly, the trend follows the distribution of $\mathrm{OH}^{*}, \mathrm{CH}^{*}$, and $\mathrm{NH}^{*}$ (Figure 6), with a more intense flame moving towards the far-right location of the system. Simultaneously, mean $\mathrm{NH}_{2}$ mole fraction, Figure 8 , is considerably enhanced for the high ammonia blends, also an expected trend. However, the distribution of $\mathrm{NH}_{2}$ across the highest ammonia blend (i.e., 20/80) is less consistent with its counterparts at lower ammonia fractions, potentially a result of the lower reactivity of ammonia and wider spread flames. Therefore, although amidogen $\left(\mathrm{NH}_{2}\right)$ is highly abundant in the $20 / 80$ case, its concentration across the flame front is well-defined only at higher methane contents with less flipping along the flame brush. It must be emphasized that the higher $\mathrm{NH}_{2}$ concentration remains in the interior part of the flame, a region that is in close contact with recirculation zones and hot products. This region, closer to the centre of the field, also follows similar trends to the $\mathrm{NH}_{2}{ }^{*}$ findings in Figure 6, with a profile close to the far left of the diagram.

Mean $\mathrm{OH}$ mole fraction was also obtained to determine the progression of this species across the flow field. Figure 9 shows how the increase in methane fraction enhances the 
concentration of $\mathrm{OH}$ radicals, spreading their appearance across the field. Interestingly, the lower concentration of $\mathrm{OH}$ in high ammonia blends is also accompanied by high $\mathrm{NH}_{2}$ concentration, shown by Figure 8 . OH results denote the low concentration of the species at the far-right of the field at high ammonia concentrations (20/80), whilst $\mathrm{OH}$ concentration at higher methane spreads across the field, shifting the centre of gravity of the radical to the right, in accord with Figure 6. Although chemiluminescence measurements of $\mathrm{OH}^{*}, \mathrm{CH}^{*}, \mathrm{NH}^{*}$, and $\mathrm{NH}_{2}{ }^{*}$ are not equal to ground base species location, there exists a correlation between both molecules that can be employed for further understanding of these flames [41]. Hence, it can be said that chemiluminescence results and $C o G$ analyses were able to qualitatively follow the distribution of major species in ammonia-based flames. The finding can be exploited for fast improvement in design methodologies and higher control in radical interaction.

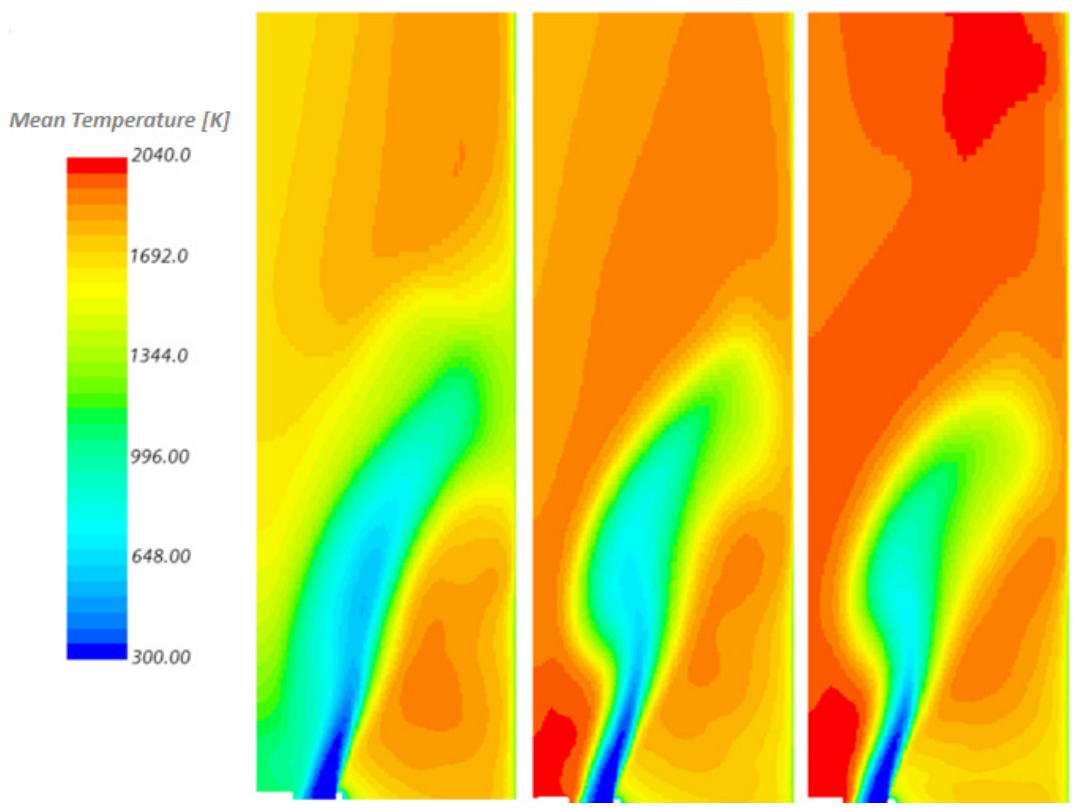

Figure 7. Mean temperature. (Left) 20/80; (Centre) 40/60; (Right) 60/40 (vol\%) methane/ammonia blends under stoichiometric conditions.

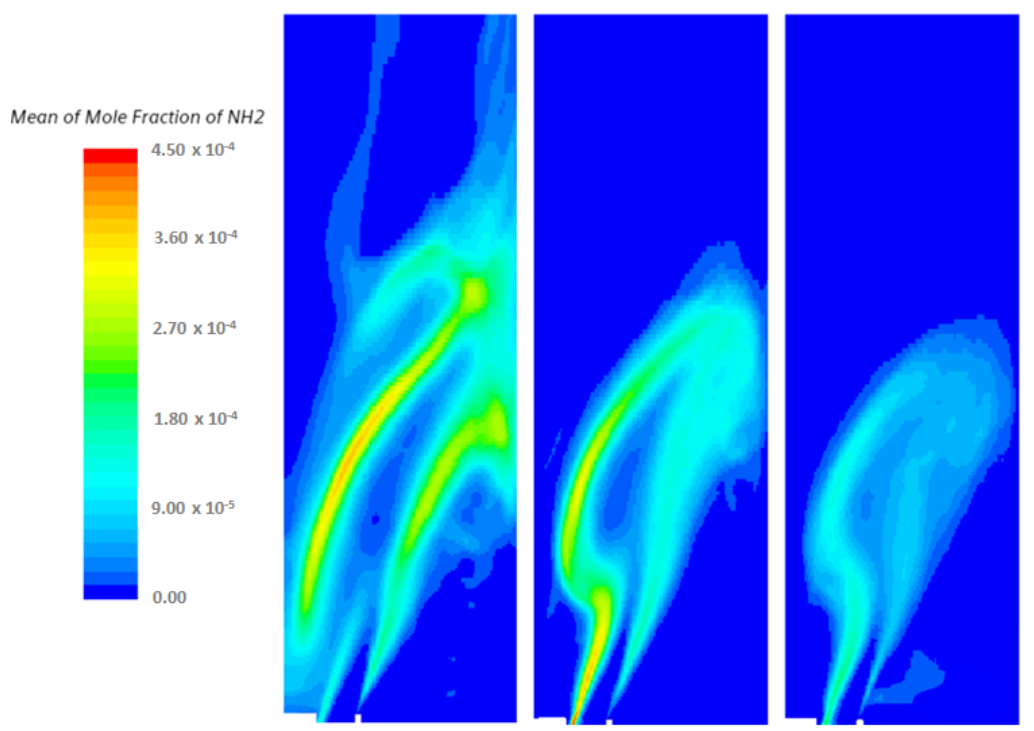

Figure 8. Mean mole fraction of NH2. (Left) 20/80; (Centre) 40/60; (Right) 60/40 (vol\%) methane/ammonia blends under stoichiometric conditions. 


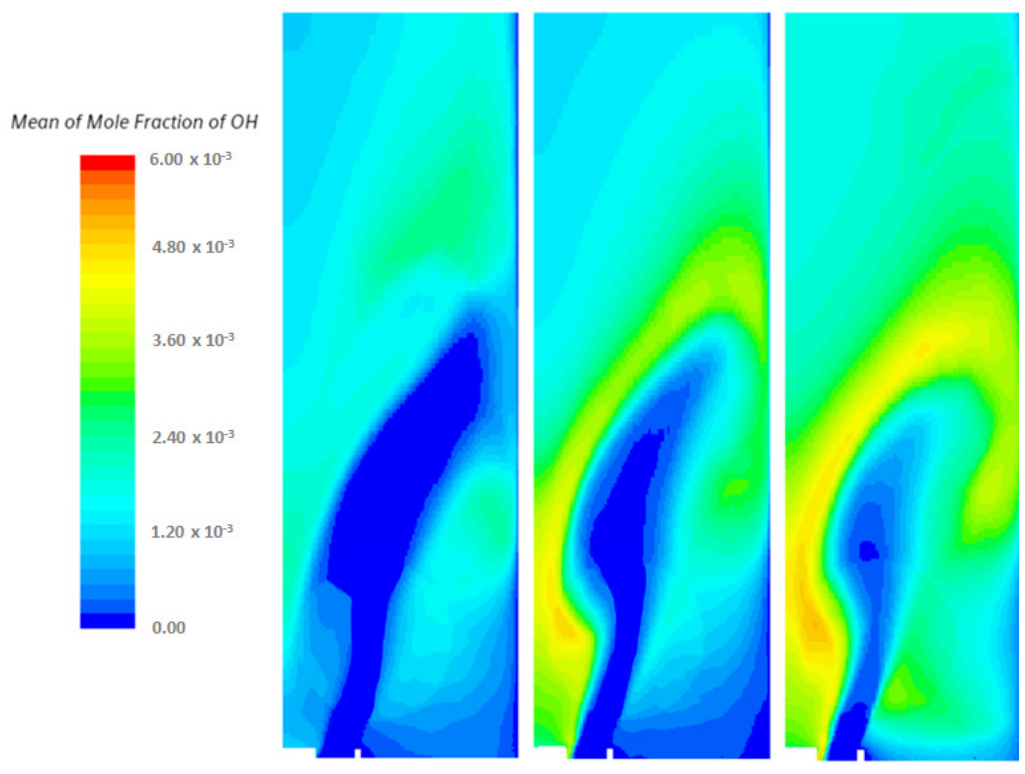

Figure 9. Mean mole fraction of OH. (Left) 20/80; (Centre) 40/60; (Right) 60/40 (vol\%) methane/ammonia blends under stoichiometric conditions.

In parallel, the CFD results gave support for the definition of an adequate methane/ ammonia blend that can be employed for high temperature profiles with elevated radical formation (which can be used for DeNOxing applications or higher combustion efficiencies [42]). It must be noticed that mole fractions of $\mathrm{NH}_{2}$ and $\mathrm{OH}$ at $40 / 60$ (vol\%) methane/ammonia conditions are extremely high in comparison with the 20/80 and the $60 / 40$ cases, respectively. Simultaneously, temperatures in the $40 / 60$ condition remain above $2000 \mathrm{~K}$, thus elucidating a mixture that not only is capable of high radical formation to enhance emissions reduction in the post-combustion zone [43] but also can provide elevated temperatures useful for engine applications.

Further analysis of the CFD results showed more intrinsic interactions between radicals and other parameters. A point of interest is the heat release rate (HRR) generated by these radicals and their reactions. Instantaneous results, Figure 10, demonstrate that the highest HRR values are achieved at higher methane content. Simultaneously, the level of heat release at high ammonia concentration is just slightly lower compared with the former.

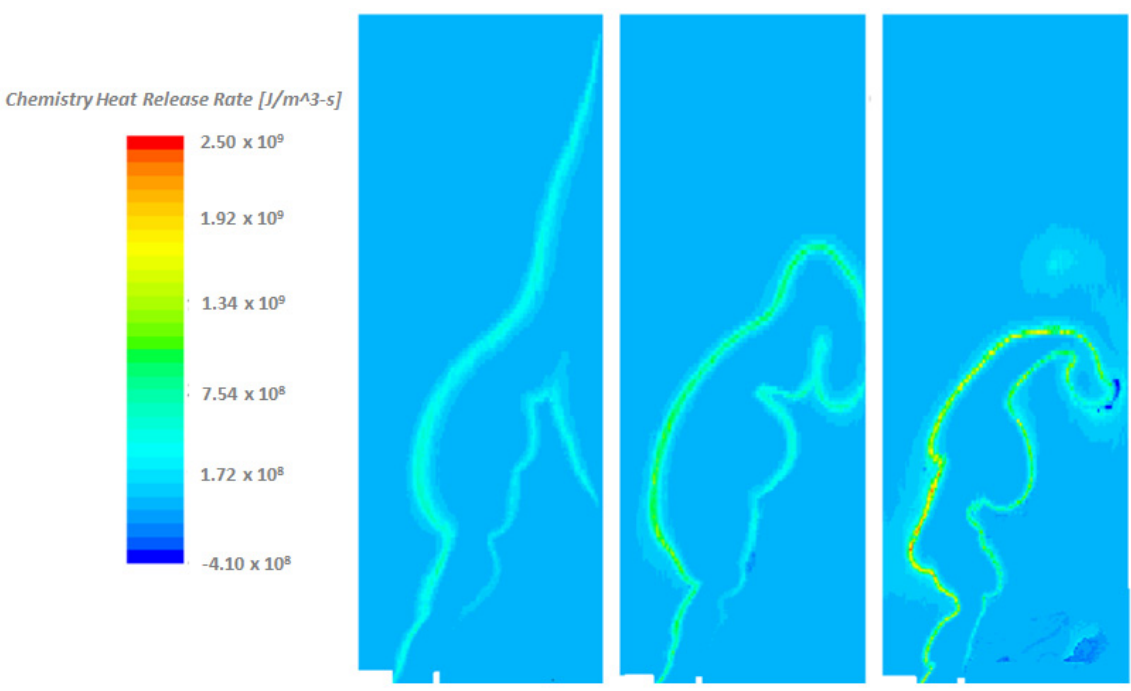

Figure 10. Instantaneous chemistry heat release rate. (Left) 20/80; (Centre) 40/60; (Right) 60/40 (vol\%) methane/ammonia blends under stoichiometric conditions. 
Most studies that employ methane-based flames for tracing thermoacoustic instabilities use $\mathrm{OH}$ and $\mathrm{CH}$ as markers for heat release, as these two radicals have a direct relationship to the heat release that affects flow fluctuations in the field. Within a combustor, the method of determining these instabilities is using the flame transfer function (FTF), which is correlated with heat release and flow fluctuations through the following equation: $10^{9}$

$$
\frac{Q^{\prime}}{\bar{Q}}=\operatorname{FTF} \frac{U \prime}{\bar{U}}
$$

where $Q^{\prime}$ represents instantaneous heat release, $U$ ' represents instantaneous velocity in the combustor, and $\bar{Q}$ and $\bar{U}$ represent their mean values accordingly. Non linearities in the combustion zone are known to be triggered by this heat release oscillation [44], which can be in phase with the dynamic pressure of the combustion system, energising the acoustic field and vice versa.

In the case of high ammonia content (20/80), the $\mathrm{CH}$ traces are considerably low (Figure 11). Hence, the high HRR observed in Figure 10 should be related to $\mathrm{OH}$. However, this also contradicts the findings in Figure 9, where the whole field is saturated by hydroxyl $(\mathrm{OH})$ radicals. Thus, the correlation $[\mathrm{NH} 2]^{*}[\mathrm{OH}]$ was explored (Figure 12). The results demonstrate that it is the combination of amidogen and hydroxyl radicals that shows an almost identical, high intensity profile to that of HRR observed in Figure 10. These findings lead to the conclusion that HRR needs to be addressed, evaluating both $\mathrm{CH}, \mathrm{OH}$, and $\mathrm{NH}_{2}$ when ammonia flames are characterised.

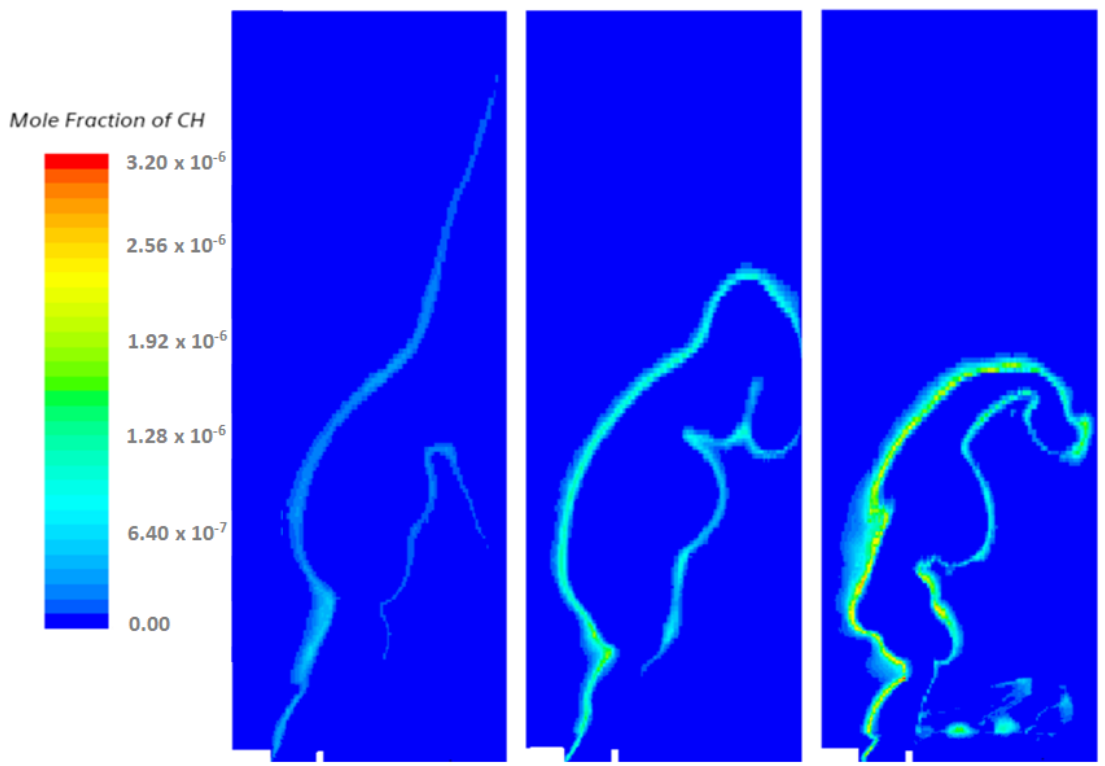

Figure 11. Instantaneous mole fraction of CH. (Left) 20/80; (Centre) 40/60; (Right) 60/40 (vol\%) methane/ammonia blends under stoichiometric conditions. 

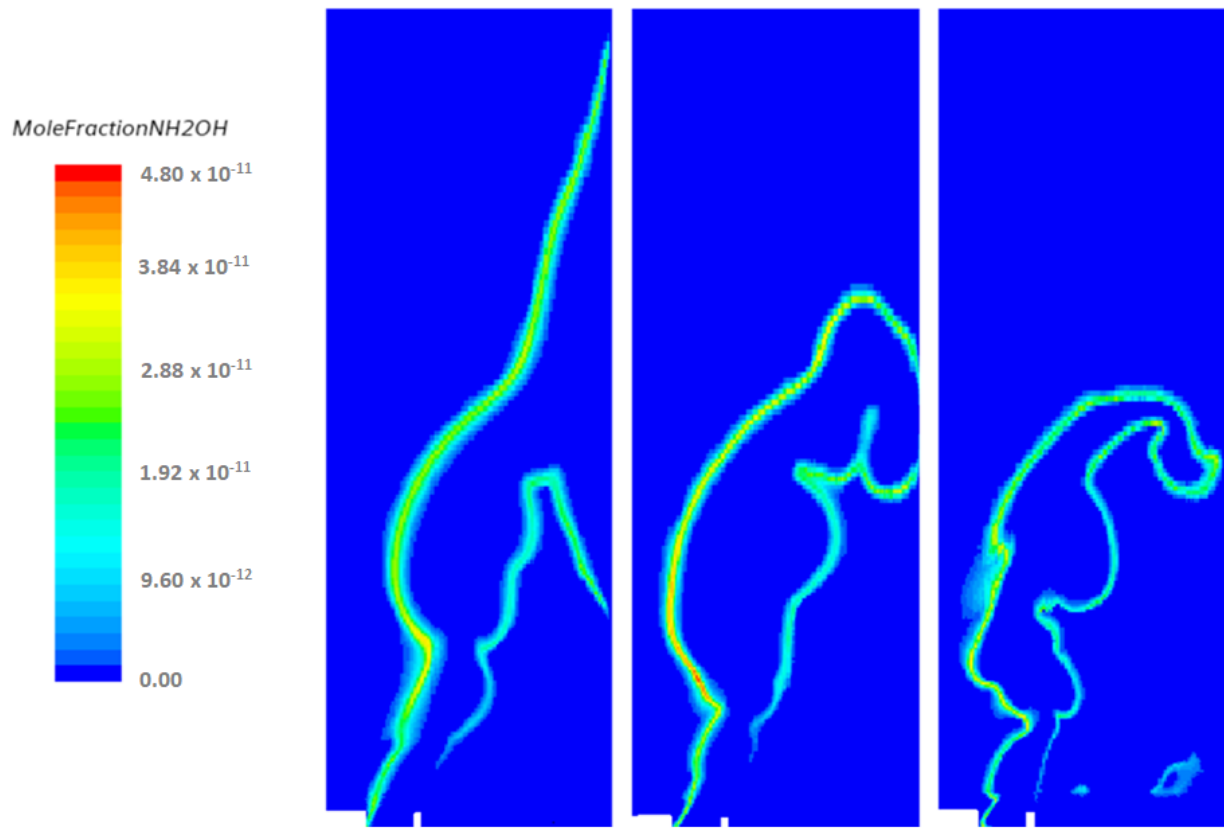

Figure 12. Instantaneous mole fraction of [NH2]*[OH]. (Left) 20/80; (Centre) 40/60; (Right) 60/40 (vol\%) methane/ammonia blends under stoichiometric conditions.

\section{Conclusions}

Experimental and numerical studies were conducted on a variety of methane/ammonia blends. The use of methane/ammonia at different concentrations was explored separately in other works. However, the comparison of various blends in swirling flows through flame characteristics, radical formation, and complex numerical modelling was attempted for the first time in this research. Results show that:

- Chemiluminescence imaging of $\mathrm{OH}^{*}, \mathrm{CH}^{*}, \mathrm{NH}^{*}$, and $\mathrm{NH}_{2}{ }^{*}$ radicals in these flames denotes complex evolution of species that can be better understood using centre of gravity $(\mathrm{CoG})$ assessments;

- The presence of $\mathrm{NH}_{2}{ }^{*}$ follows different trends to $\mathrm{CH}^{*}, \mathrm{NH}^{*}$, and $\mathrm{OH}^{*} . \mathrm{NH}_{2}{ }^{*}$ tends to concentrate at the core of the flame under rich conditions, whilst lean conditions show a wider distribution towards the end of the flame zone;

- A blend of 40/60 (vol\%) methane/ammonia shows the best potential for use in combustion applications, with the formation of large pools of radicals that can be employed for second-stage combustion. Additionally, the temperatures are sufficiently high for these blends to be employed as a substitute for fossil fuels;

- Heat release rates (HRR) need to be addressed in methane/ammonia blends using not only $\mathrm{OH}$ and $\mathrm{CH}$ signatures but also $\mathrm{NH}_{2}$, as the combination of these three molecules shows to be more in line with the high HRR produced by ammonia blends.

Author Contributions: Conceptualization, A.V.-M.; methodology, S.M., M.K. and M.O.V.-Z.; software, M.E.T.-d.-C.; validation, S.M.; formal analysis, M.O.V.-Z., C.L.O.-R. and A.V.-M.; writingreview and editing, M.E.T.-d.-C., M.K. and C.L.O.-R.; funding acquisition, A.V.-M. All authors have read and agreed to the published version of the manuscript.

Funding: This research was funded by ESPRC through the program SAFE-Pilot AGT (EP/T009314/1).

Institutional Review Board Statement: Not applicable.

Informed Consent Statement: Not applicable.

Data Availability Statement: Information on the data underpinning the results presented here, including how to access them, can be found in the Cardiff University data catalogue at http:/ / orca.cf. ac.uk/144818/. 
Acknowledgments: Cardiff University authors gratefully acknowledge the support from Malcolm Seaborn to conduct the experimental trials and setup of the equipment at Cardiff, UK.

Conflicts of Interest: The authors declare no conflict of interest.

\section{References}

1. Elishav, O.; Lis, B.M.; Miller, E.M.; Arent, D.J.; Valera-Medina, A.; Dana, A.G.; Shter, G.E.; Grader, G.S. Progress and Prospective of Nitrogen-Based Alternative Fuels. Chem. Rev. 2020, 120, 5352-5436. [CrossRef] [PubMed]

2. Valera-Medina, A.; Amer-Hatem, F.; Azad, A.K.; Dedoussi, I.C.; de Joannon, M.; Fernandes, R.X.; Glarborg, P.; Hashemi, H.; He, X.; Mashruk, S.; et al. Review on Ammonia as a Potential Fuel: From Synthesis to Economics. Energy Fuels 2021, 35, 6964-7029. [CrossRef]

3. Valera-Medina, A.; Roldan, A. Ammonia from Steelworks. In Sustainable Ammonia Production; Springer: Cham, Switzerland, 2020. [CrossRef]

4. Salmon, N.; Bañares-Alcántara, R. Green ammonia as a spatial energy vector: A review. Sustain. Energy Fuels 2021. [CrossRef]

5. Bicer, Y.; Dincer, I. Life cycle assessment of ammonia utilization in city transportation and power generation. J. Clean. Prod. 2018, 170, 1594-1601. [CrossRef]

6. Siddiqui, O.; Dincer, I. Experimental investigation and assessment of direct ammonia fuel cells utilizing alkaline molten and solid electrolytes. Energy 2019, 169, 914-923. [CrossRef]

7. Razon, L.F.; Valera-Medina, A. A Comparative Environmental Life Cycle Assessment of the Combustion of Ammonia/Methane Fuels in a Tangential Swirl Burner. Front. Chem. Eng. 2021, 3. [CrossRef]

8. Duijm, N.J.; Markert, F.; Paulsen, J.L. Safety Assessment of Ammonia as a Transport Fuel; Risø DTU National Laboratory for Sustainable Energy: Roskilde, Denmark, 2005

9. Quest Consultants Inc. Comparative Quantitative Risk Analysis of Motor Gasoline, LPG and Anhydrous Ammonia as an Automotive Fuel; Quest: Norman, OK, USA, 2009.

10. Crolius, S.; Pugh, D.; Morris, S.; Valera-Medina, A. Safety Aspects. In Techno-Economic Challenges Ammon as an Energy Vector; Elsevier: Amsterdam, The Netherlands, 2021; pp. 221-257.

11. Kondo, S.; Takahashi, A.; Tokuhashi, K.; Sekiya, A. RF number as a new index for assessing combustion hazard of flammable gases. J. Hazard. Mater. 2002, 93, 259-267. [CrossRef]

12. NCRFP. Report 18, Marine Highway Transport of Toxic Inhalation Hazard Materials. 2012. Available online: https://www.nap. edu/catalog/22737/marine-highway-transport-of-toxic-inhalation-hazard-materials (accessed on 12 June 2021).

13. Crolius, S. An Open Letter to the International Energy Agency. Ammon Energy 2019. Available online: https://www. ammoniaenergy.org/an-open-letter-to-the-international-energy-agency/ (accessed on 12 July 2019).

14. De Vries, N.; Okafor, E.; Gutesa-Bozo, M.; Xiao, H.; Valera-Medina, A. Use of Ammonia for Heat, Power and Propulsion. In Techno-Economic Challenges Green Ammon as an Energy Vector; Elsevier: Amsterdam, The Netherlands, 2020; pp. 105-154. [CrossRef]

15. Hayakawa, A.; Goto, T.; Mimoto, R.; Kudo, T.; Kobayashi, H. NO formation/reduction mechanisms of ammonia/air premixed flames at various equivalence ratios and pressures. Mech. Eng. J. 2015, 2, 14-00402. [CrossRef]

16. Okafor, E.C.; Somarathne, K.K.A.; Hayakawa, A.; Kudo, T.; Kurata, O.; Iki, N.; Kobayashi, H. Towards the development of an efficient low-NOx ammonia combustor for a micro gas turbine. Proc. Combust. Inst. 2019, 37, 4597-4606. [CrossRef]

17. Okafor, E.C.; Somarathne, K.K.A.; Ratthanan, R.; Hayakawa, A.; Kudo, T.; Kurata, O.; Iki, N.; Tsujimura, T.; Furutani, H.; Kobayashi, H. Control of NOx and other emissions in micro gas turbine combustors fuelled with mixtures of methane and ammonia. Combust. Flame 2020, 211, 406-416. [CrossRef]

18. Pugh, D.; Medina, A.V.; Bowen, P.; Giles, A.; Goktepe, B.; Runyon, J.P.; Morris, S.; Hewlett, S.; Marsh, R. Emissions Performance of Staged Premixed and Diffusion Combustor Concepts for an NH3/Air Flame With and Without Reactant Humidification. J. Eng. Gas Turbines Power 2021, 143, 1-10. [CrossRef]

19. Pugh, D.; Bowen, P.; Valera-Medina, A.; Giles, A.; Runyon, J.; Marsh, R. Influence of steam addition and elevated ambient conditions on NOx reduction in a staged premixed swirling NH3/H2 flame. Proc. Combust. Inst. 2018, 37, 5401-5409. [CrossRef]

20. Chen, J.; Jiang, X.; Qin, X.; Huang, Z. Effect of hydrogen blending on the high temperature auto-ignition of ammonia at elevated pressure. Fuel 2020, 287, 119563. [CrossRef]

21. Thomas, D.; Northrop, W. Ammonia-Hydrogen Combustion in Diffusion Flames. In Proceedings of the 38th International Symposium on Combustion, Adelaide, Australia, 24-29 January 2021.

22. Iki, N.; Kurata, O.; Matsunuma, T.; Inoue, T.; Suzuki, M.; Tsujimura, T.; Furutani, H. Micro Gas Turbine Firing Kerosene and Ammonia. In Proceedings of the Turbo Expo: Power for Land, Sea, and Air, Montreal, QC, Canada, 15-19 June 2015; Volume 8. [CrossRef]

23. Valera-Medina, A.; Marsh, R.; Runyon, J.; Pugh, D.; Beasley, P.; Hughes, T.; Bowen, P. Ammonia-methane combustion in tangential swirl burners for gas turbine power generation. Appl. Energy 2017, 185, 1362-1371. [CrossRef]

24. Xiao, H.; Howard, M.; Valera-Medina, A.; Dooley, S.; Bowen, P.J. Study on Reduced Chemical Mechanisms of Ammonia/Methane Combustion under Gas Turbine Conditions. Energy Fuels 2016, 30, 8701-8710. [CrossRef]

25. Khateeb, A.A.; Guiberti, T.F.; Zhu, X.; Younes, M.; Jamal, A.; Roberts, W.L. Stability limits and NO emissions of technicallypremixed ammonia-hydrogen-nitrogen-air swirl flames. Int. J. Hydrogen Energy 2020, 45, 22008-22018. [CrossRef] 
26. Valera-Medina, A.; Morris, S.; Runyon, J.; Pugh, D.; Marsh, R.; Beasley, P.; Hughes, T. Ammonia, Methane and Hydrogen for Gas Turbines. Energy Procedia 2015, 75, 118-123. [CrossRef]

27. Honzawa, T.; Kai, R.; Okada, A.; Valera-Medina, A.; Bowen, P.J.; Kurose, R. Predictions of NO and CO emissions in ammonia/methane/air combustion by LES using a non-adiabatic flamelet generated manifold. Energy 2019, 186, 115771. [CrossRef]

28. Montgomery, M.J.; Kwon, H.; Dreyer, J.A.; Xuan, Y.; McEnally, C.S.; Pfefferle, L.D. Effect of ammonia addition on suppressing soot formation in methane co-flow diffusion flames. Proc. Combust. Inst. 2020, 38, 2497-2505. [CrossRef]

29. Stagni, A.; Cavallotti, C.; Arunthanayothin, S.; Song, Y.; Herbinet, O.; Battin-Leclerc, F.; Faravelli, T. An experimental, theoretical and kinetic-modeling study of the gas-phase oxidation of ammonia. React. Chem. Eng. 2020, 5, 696-711. [CrossRef]

30. Mikulčić, H.; Baleta, J.; Wang, X.; Wang, J.; Qi, F.; Wang, F. Numerical simulation of ammonia/methane/air combustion using reduced chemical kinetics models. Int. J. Hydrog. Energy 2021, 46, 23548-23563. [CrossRef]

31. Cai, T.; Zhao, D.; Li, X.; Shi, B.; Li, J. Mitigating NO emissions from an ammonia-fueled micro-power system with a perforated plate implemented. J. Hazard. Mater. 2020, 401, 123848. [CrossRef]

32. Kujiraoka, H.; Izumi, T.; Yoshizuru, Y.; Suemasy, T.; Ueda, M.; Niki, T.; Itou, T.; Nishio, M.; Murai, R.; Akamatsu, F. Evaluation of the Cement Clinker Fired in the Combustion Furnace of Heavy-Oil and NH3. NH3 Assoc 2018. Available online: https://nh3 fuelassociation.org/wp-content/uploads/2018/12/1700-549g181031_Kujiraoka_UBE_NoAPP.pdf (accessed on 24 June 2019).

33. Mitsubishi Heavy Industries Group. Mitsubishi Power Commences Development of World's First Ammonia-fired 40MW Class Gas Turbine System 2021. Available online: https://power.mhi.com/news/20210301.html (accessed on 13 August 2021).

34. Zhang, F.; Chen, G.; Wu, D.; Li, T.; Zhang, Z.; Wang, N. Characteristics of Ammonia/Hydrogen Premixed Combustion in a Novel Linear Engine Generator. Proceedings 2020, 58, 2. [CrossRef]

35. Dantec Dynamics. BSA Flow Software for LDA 2017. Available online: https://www.dantecdynamics.com/download-login (accessed on 28 September 2020).

36. Van Assen, H.H.; Egmont-Petersen, M.; Reiber, J.J. Accurate object localization in gray level images using the center of gravity measure: Accuracy versus precision. IEEE Trans. Image Process. 2002, 11, 1379-1384. [CrossRef]

37. Eriksson, P. The Zimont TFC Model Applied to Premixed Bluff Body Stabilized Combustion Using Four Different RANS Turbulence Models. In Proceedings of the Turbo Expo: Power for Land, Sea, and Air, Montreal, QC, Canada, 14-17 May 2007; pp. 353-361. [CrossRef]

38. Baej, H.; Valera-Medina, A.; Bowen, P.; Syred, N.; O’Doherty, T.; Marsh, R. Impacts on Blowoff by a Variety of CRZs Using Various Gases for Gas Turbines. Energy Procedia 2014, 61, 1606-1609. [CrossRef]

39. Siemens. Complex Chemistry. Star-CCM+ Doc 2019. Available online: https://documentation.thesteveportal.plm.automation. siemens.coml (accessed on 24 September 2019).

40. Vigueras-Zuniga, M.-O.; Tejeda-Del-Cueto, M.-E.; Vasquez-Santacruz, J.-A.; Herrera-May, A.-L.; Valera-Medina, A. Numerical Predictions of a Swirl Combustor Using Complex Chemistry Fueled with Ammonia/Hydrogen Blends. Energies 2020, $13,288$. [CrossRef]

41. Pugh, D.; Runyon, J.; Bowen, P.; Giles, A.; Valera-Medina, A.; Marsh, R.; Goktepe, B.; Hewlett, S. An investigation of ammonia primary flame combustor concepts for emissions reduction with $\mathrm{OH}^{*}, \mathrm{NH}^{*}$ and $\mathrm{NH}^{*}$ chemiluminescence at elevated conditions. Proc. Combust. Inst. 2020, 38, 6451-6459. [CrossRef]

42. Glarborg, P.; Dam-Johansen, K.; Miller, J.A.; Kee, R.J.; Coltrin, M.E. Modeling the thermal DENOx process in flow reactors. Surface effects and Nitrous Oxide formation. Int. J. Chem. Kinet. 1994, 26, 421-436. [CrossRef]

43. Valera-Medina, A.; Mashruk, S.; Xiao, H.; Chiong, M.-C.; Tung Chong, C. Ammonia/Hydrogen Blends for Zero-Carbon Energy. In Proceedings of the 8th International Conference on Fluid Mechanics, Virtual, 25-28 September 2018.

44. Stow, S.R.; Dowling, A.P. Thermoacoustic Oscillations in an Annular Combustor. In Proceedings of the Turbo Expo: Power for Land, Sea, and Air, New Orleans, LA, USA, 4-7 June 2001. [CrossRef] 